\title{
Endocrine
}

\section{IN VITRO ANTITUMOR ACTIVITY OF PROGESTERONE IN HUMAN ADRENOCORTICAL CARCINOMA

\author{
--Manuscript Draft--
}

\begin{tabular}{|c|c|c|}
\hline Manuscript Number: & \multicolumn{2}{|l|}{ ENDO-D-18-00620R1 } \\
\hline Corresponding Author: & \multicolumn{2}{|c|}{$\begin{array}{l}\text { Alfredo Berruti } \\
\text { Azienda Ospedaliera Spedali Civili di Brescia and University of Brescia } \\
\text { ITALY }\end{array}$} \\
\hline \multicolumn{3}{|l|}{$\begin{array}{l}\text { Corresponding Author Secondary } \\
\text { Information: }\end{array}$} \\
\hline Corresponding Author's Institution: & \multicolumn{2}{|c|}{ Azienda Ospedaliera Spedali Civili di Brescia and University of Brescia } \\
\hline \multicolumn{3}{|l|}{$\begin{array}{l}\text { Corresponding Author's Secondary } \\
\text { Institution: }\end{array}$} \\
\hline \multirow[t]{16}{*}{ Order of Authors: } & \multicolumn{2}{|l|}{ Martina Fragni } \\
\hline & \multicolumn{2}{|l|}{ Chiara Fiorentini } \\
\hline & \multicolumn{2}{|l|}{ Elisa Rossini } \\
\hline & \multicolumn{2}{|l|}{ Simona Fisogni } \\
\hline & \multicolumn{2}{|l|}{ Sara Vezzoli } \\
\hline & \multicolumn{2}{|l|}{ Sara A Bonini } \\
\hline & \multicolumn{2}{|l|}{ Cristina Dalmiglio } \\
\hline & \multicolumn{2}{|l|}{ Guido A.M. Tiberio } \\
\hline & \multicolumn{2}{|l|}{ Valentina Salvi } \\
\hline & \multicolumn{2}{|l|}{ Daniela Bosisio } \\
\hline & \multicolumn{2}{|l|}{ Massimo Terzolo } \\
\hline & \multicolumn{2}{|l|}{ Mariacristina Missale } \\
\hline & \multicolumn{2}{|l|}{ Fabio Facchetti } \\
\hline & \multicolumn{2}{|l|}{ Maurizio Memo } \\
\hline & \multicolumn{2}{|l|}{ Alfredo Berruti } \\
\hline & \multicolumn{2}{|l|}{ Sandra Sigala } \\
\hline \multicolumn{3}{|c|}{ Order of Authors Secondary Information: } \\
\hline \multirow[t]{2}{*}{ Funding Information: } & $\begin{array}{l}\text { Associazione Italiana per la Ricerca sul } \\
\text { Cancro } \\
\text { (IG17678) }\end{array}$ & Prof Massimo Terzolo \\
\hline & $\begin{array}{l}\text { Associazione Italiana per la Ricerca sul } \\
\text { Cancro } \\
\text { (IG14411) }\end{array}$ & Prof. Alfredo Berruti \\
\hline
\end{tabular}




\begin{tabular}{|c|c|c|}
\hline & $\begin{array}{l}\text { Fondazione Camillo Golgi } \\
\text { (not applicable) }\end{array}$ & Prof. Alfredo Berruti \\
\hline & $\begin{array}{l}\text { Private Donations } \\
\text { (not applicable) }\end{array}$ & Prof. Alfredo Berruti \\
\hline Abstract: & \multicolumn{2}{|c|}{$\begin{array}{l}\text { Purpose. The management of patients with adrenocortical carcinoma (ACC) is } \\
\text { challenging. As mitotane and chemotherapy show limited efficacy, there is an urgent } \\
\text { need to develop therapeutic approaches. The aim of this study was to investigate the } \\
\text { antitumor activity of progesterone and explore the molecular mechanisms underlying } \\
\text { its cytotoxic effects in the NCI-H295R cell line and primary cell cultures derived from } \\
\text { ACC patients. } \\
\text { Methods. Cell viability, cell cycle and apoptosis were analyzed in untreated and } \\
\text { progesterone-treated ACC cells. The ability of progesterone to affect the Wnt/ } \beta \text {-catenin } \\
\text { pathway in } \mathrm{NCl}-\mathrm{H} 295 \mathrm{R} \text { cells was investigated by immunofluorescence. Progesterone } \\
\text { and mitotane combination experiments were also performed to evaluate their } \\
\text { interaction on NCl-H295R cell viability. } \\
\text { Results. We demonstrated that progesterone exerted a concentration-dependent } \\
\text { inhibition of ACC cell viability. Apoptosis was the main mechanism, as demonstrated } \\
\text { by a significant increase of apoptosis and cleaved-Caspase-3 levels. Reduction of } \beta- \\
\text { catenin nuclear translocation may contribute to the progesterone cytotoxic effect. The } \\
\text { progesterone antineoplastic activity was synergically increased when mitotane was } \\
\text { added to the cell culture medium. } \\
\text { Conclusions. Our results show that progesterone has antineoplastic activity in ACC } \\
\text { cells. The synergistic cytotoxic activity of progesterone with mitotane provides the } \\
\text { rationale for testing this combination in a clinical study. }\end{array}$} \\
\hline Response to Reviewers: & \multicolumn{2}{|c|}{ 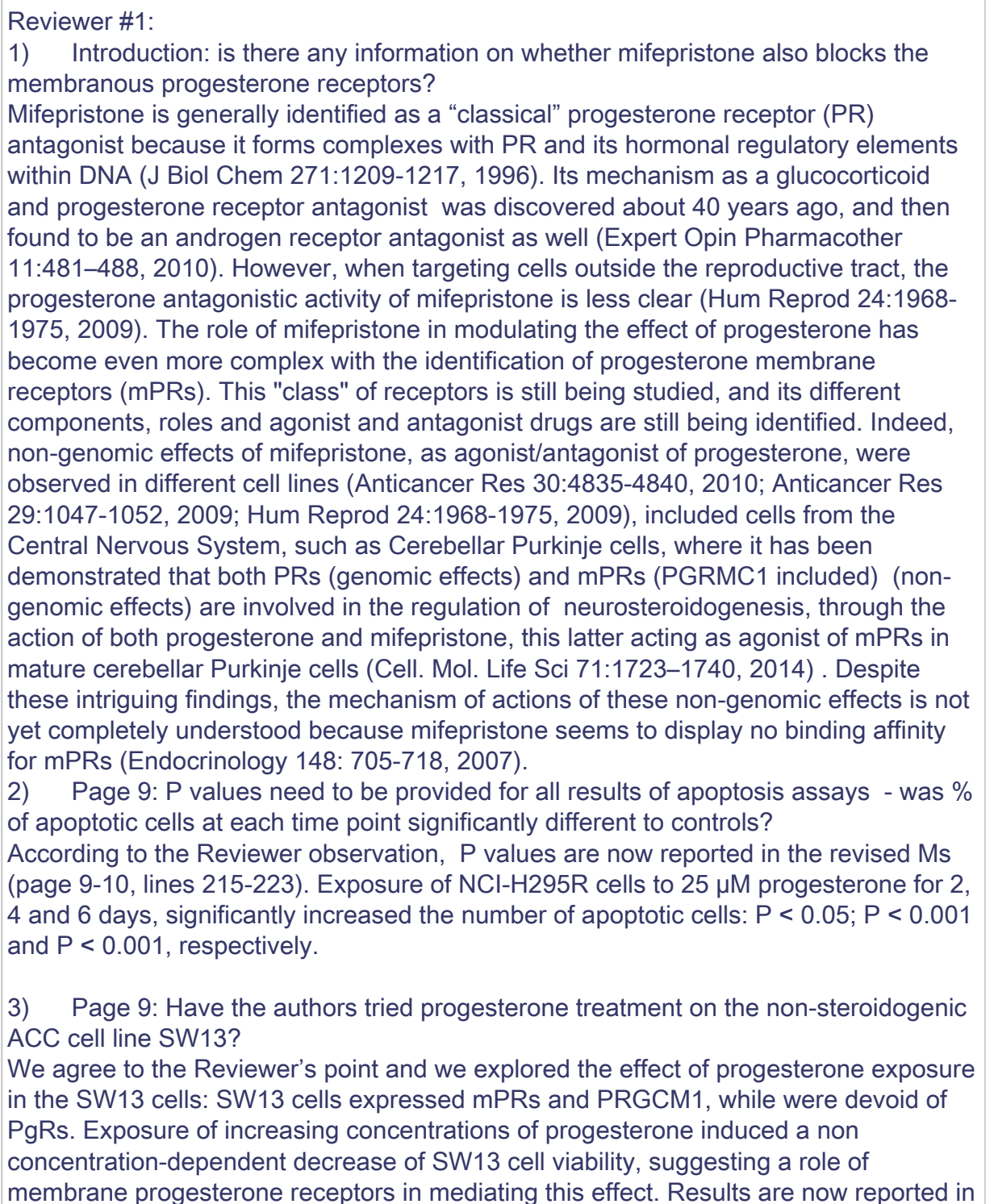 } \\
\hline
\end{tabular}


Supplemental Figure 4, and commented at page 12, lines 274-284. This is an intriguing result, that deserves to be deepened with further experiments, in order to establish the exact contribution of the different progesterone receptor components in inducing reduction of cell viability.

The progesterone mechanism of action thus becomes very complex, also in light of the evidence showing a different effect of progesterone, depending on many variables, such as the type of cells, the genomic and/or non genomic effects linked to the progesterone receptor expression and the concentration of hormone present (reviewed in Expert Rev Endocrinol Metab. 12(3):187-197, 2017). Accordingly, the non steroidogenic SW13 cell line represents a different cell phenotype compared to $\mathrm{NCl}$ H295R cells, as it has been established from a grade IV primary small cell carcinoma in the adrenal cortex, with their exact histopathologic characteristics still under investigation (Mol Cell Endocrinol. 351(1):58-65, 2012).

Although these preliminary results are of interest, they are outside the main topic of this Ms and, indeed, they will be the subject of experiments currently underway in the laboratory. This point is now underlined in the Ms: page 13, lines 295-308).

4) Page 10: The numerical result, including $p$ value, should be quoted for the reported increase in cells in sub-G0 phase

According to the Reviewer suggestion, the numerical result of cells in sub-G0 phase, and $P$ value, are now reported in the revised Ms (page 10, line 230-231).

5) Page 10: Were any other of the kinases that are reported as targets of $\mathrm{mPgR}$ tested?

In the present Ms, experiments measuring Erk and phospho-Erk was conducted only to investigate whether the mPRs expressed by $\mathrm{NCl}-\mathrm{H} 295 \mathrm{R}$ cells were functionally active after stimulation with progesterone itself; therefore we measured the expression of only one of the kinases that are part of the non-genomic progesterone effects. We are aware that there are numerous intracellular pathways involved, as demonstrated in several works and well revised in the paper of Segars and coworkers (Trends Endocrinol. Metab. 28: 656-668, 2017); however, as above pointed out, the characterization of the contribution of the different progesterone receptor components in mediating its cytotoxic effect in ACC cells is beyond the scope of this work. Accordingly, these observations deserve an experimental investigation that is currently underway in the laboratory.

6) Has progesterone been measured in the plasma of the 5 ACC patients whose tumours were used for the primary culture work?

We did not measure the progesterone levels in patients.

7) Clinical studies employing steroid profiling (e.g. Arlt et al, JCEM 2011; Kerkhofs et al, Horm Cancer 2015) have revealed that most steroid-producing ACCs are associated with excessive secretion of progesterone, yet most epidemiological studies also suggest that steroidogenic ACCs have a more aggressive clinical course than their non-secreting counterparts. How do the authors reconcile their findings with these clinical observations?

The Reviewer is right, hormone hypersecretion as a whole is associated with poorer prognosis in ACC patients, however this negative relationship was observed for cortisol hypersecretion either alone or associated with androgens. We have observed that ACC patients with pure hyperandrogenism have a better prognosis as compared with cortisol secreting or non secreting patients (Berruti et al. Endocr Relat Cancer 2005). To our knowledge no data are available on the prognostic role of progesterone receptor and circulating progesterone levels in ACC. 


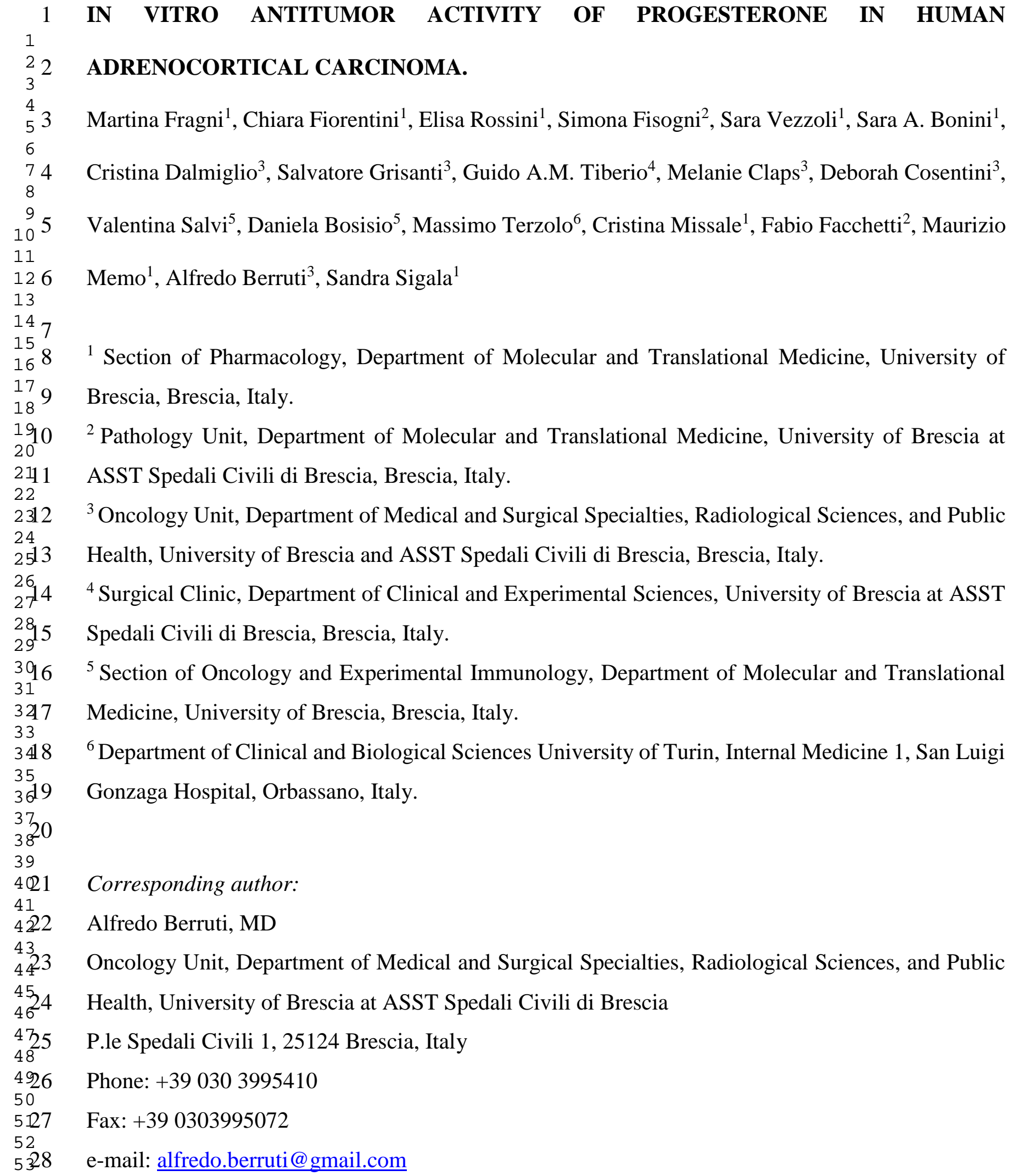

${ }^{1}$ Section of Pharmacology, Department of Molecular and Translational Medicine, University of Brescia, Brescia, Italy.

${ }^{2}$ Pathology Unit, Department of Molecular and Translational Medicine, University of Brescia at ASST Spedali Civili di Brescia, Brescia, Italy.

${ }^{3}$ Oncology Unit, Department of Medical and Surgical Specialties, Radiological Sciences, and Public Health, University of Brescia and ASST Spedali Civili di Brescia, Brescia, Italy.

${ }^{4}$ Surgical Clinic, Department of Clinical and Experimental Sciences, University of Brescia at ASST Spedali Civili di Brescia, Brescia, Italy.

${ }^{5}$ Section of Oncology and Experimental Immunology, Department of Molecular and Translational Medicine, University of Brescia, Brescia, Italy.

${ }^{6}$ Department of Clinical and Biological Sciences University of Turin, Internal Medicine 1, San Luigi Gonzaga Hospital, Orbassano, Italy.

\section{Corresponding author:}

Alfredo Berruti, MD

Oncology Unit, Department of Medical and Surgical Specialties, Radiological Sciences, and Public Health, University of Brescia at ASST Spedali Civili di Brescia

P.le Spedali Civili 1, 25124 Brescia, Italy

Phone: +39030 3995410

Fax: +390303995072

e-mail: alfredo.berruti@gmail.com

Conflicts of interest: Authors have nothing to disclose. 


\section{Funding}

1

33 This work was supported by: AIRC project IG17678 (PI: M.T.); AIRC project IG14411 (PI: A.B.);

${ }_{5}^{4}$ Fondazione Camillo Golgi, Brescia; University of Brescia local grants; private donation of "gli 6 Amici di Andrea" in memory of Andrea Gadeschi; private grant from the amateur dramatics group

“Attori non per caso", Parish church of Collio Valtrompia (Brescia). M.F. was supported by a grant 11 1237 from the Italian Society of Pharmacology. 


\begin{abstract}
Purpose. The management of patients with adrenocortical carcinoma (ACC) is challenging. As mitotane and chemotherapy show limited efficacy, there is an urgent need to develop therapeutic approaches. The aim of this study was to investigate the antitumor activity of progesterone and explore the molecular mechanisms underlying its cytotoxic effects in the NCI-H295R cell line and primary cell cultures derived from ACC patients.
\end{abstract}

Methods. Cell viability, cell cycle and apoptosis were analyzed in untreated and progesterone-treated ACC cells. The ability of progesterone to affect the Wnt/3-catenin pathway in NCI-H295R cells was investigated by immunofluorescence. Progesterone and mitotane combination experiments were also performed to evaluate their interaction on NCI-H295R cell viability.

Results. We demonstrated that progesterone exerted a concentration-dependent inhibition of ACC cell viability. Apoptosis was the main mechanism, as demonstrated by a significant increase of apoptosis and cleaved-Caspase-3 levels. Reduction of $\beta$-catenin nuclear translocation may contribute to the progesterone cytotoxic effect. The progesterone antineoplastic activity was synergically increased when mitotane was added to the cell culture medium.

Conclusions. Our results show that progesterone has antineoplastic activity in ACC cells. The synergistic cytotoxic activity of progesterone with mitotane provides the rationale for testing this combination in a clinical study.

Abbreviations: ACC, adrenocortical carcinoma; PgR, progesterone receptor; CI, confidence interval; MTT, 3-(4,5-Dimethyl-2-thiazol)-2,5-diphenyl-2H-tetrazolium bromide; mPR, progesterone membrane receptor; PGRMC1, progesterone receptor membrane component 1.

Keywords: adrenocortical carcinoma, progesterone, progesterone receptor, cell viability. 


\section{Introduction}

Adrenocortical carcinoma (ACC) is a rare aggressive endocrine tumor [1] that in approximately 50\% of adults is capable of hormone secretion [2]. Cushing's syndrome is the most commonly associated endocrine disorder [3]. The Systemic therapies have a limited efficacy [4-6]; thus, the prognosis of advanced ACC patients, not amenable to radical extirpation, is poor with a 5 year survival rate of $15 \%$ [7]; moreover, histological and molecular diagnostic parameters are not still completely shared [8]. Mitotane (o, $\mathrm{p}^{\prime}$-dichlorodiphe nyldichloroethane, o, $\mathrm{p}^{\prime}$-DDD) is the reference drug; however, toxicity and narrow therapeutic index limit its efficacy [9]. Therefore, there is an urgent need of new therapeutic approaches.

We have recently observed that abiraterone acetate (abiraterone) has both antisecretive and antitumor activities in ACC cell lines [10]. The antisecretive effect of abiraterone is mediated by the inhibition of 17alpha-hydroxylase/17,20-lyase (CYP17A1), a key enzyme for steroid hormone synthesis [11, 12] leading to a rapid inhibition of cortisol secretion [10, 13]. Abiraterone mechanism of action may involve, at least in part, the $\mathrm{Wnt} / \beta$-catenin signaling pathway [10] that is constitutively active in approximatively $30 \%$ of ACC [14] and is a potential target for new molecular therapies. The cytotoxic effect of abiraterone remains to be fully elucidated, but evidence strongly indicate that it is directly associated with the drug-induced increase of progesterone levels, requiring the activation of the intracellular progesterone receptors (PgRs). Interestingly, in addition to the well known role of PgRs as nuclear transcription factors, different members of membrane progesterone receptors (mPRs) have been identified and the term "extranuclear" or "non-genomic" effects of progesterone was suggested to specifically defined mPR functions [15]. Another putative membrane-specific progesterone receptor, distinct from known $\mathrm{mPRs}$ and nuclear $\mathrm{PgR}$, was isolated from different tissues and called Progesterone Receptor Membrane Component 1 (PGRMC1) [15, 16]. The extranuclear receptor activation leads to a rapid signaling, linked to various second messenger cascades, including extracellular signal-regulated kinases (Erk 1/2, p42/44, p38 MAPKs) [15] and regulation of 
intracellular calcium mobilization [16]. These effects are progesterone-dependent but independent of PgR transcriptional activity, and are integral part of progesterone cellular effects [17].

In this study, we investigated the cytotoxic effects of progesterone and the molecular mechanisms underlying its antitumor activity in NCI-H295R ACC cell line [18] and in ACC primary cell cultures derived from patients with either cortisol-secreting or non-secreting ACC.

\section{Materials and Methods}

\section{Cell lines}

NCI-H295R ACC cell line was obtained from the American Type Culture Collection (ATCC) and cultured as suggested by the manufacturer. Cells were authenticated by the AmpFISTR Identifiler PCR amplification kit (Applied Biosystems, Foster City, CA, USA). Media and supplements were supplied by Sigma Italia (Milan, Italy). SW13 cell line was obtained from ATCC and cultured as suggested by the manufacturer.

\section{Primary cell cultures}

Human ACC primary cells were derived from three patients with cortisol-secreting tumors (ACC01, ACC02 and ACC16) and from two patients with non-secreting tumors (ACC03, ACC08). Clinical and histological features are reported in Table 1. After surgical removal, cells were enzymatically digested with $(0.1 \mathrm{mg} / \mathrm{mL})$ collagenase (Sigma Italia, Milan, Italy) and cultured in the same medium of NCI-H295R cells. The project was approved by the local Ethical Committee and written informed consent was obtained from all patients.

\section{Immunohistochemistry}

Immunohistochemistry for $\mathrm{PgR}$ was performed on $2 \mu \mathrm{m}$ sections from formalin fixed-paraffin embedded ACC tissues. Ventana BenchMark Ultra platform was used according to the manufacturer's recommended settings. Ultra Cell Conditioning 1 (CC1) solution was used for heat-induced epitope retrieval $\left(95^{\circ} \mathrm{C}\right.$ for $\left.64 \mathrm{~min}\right)$. Slides were incubated $\left(36^{\circ} \mathrm{C}\right.$ for $\left.16 \mathrm{~min}\right)$ with the ready-to-use anti-PgR antibody (monoclonal rabbit anti-human PR clone 1E2, Roche) [19] and followed by UltraView 
Universal DAB Detection Kit. Positive and negative controls from breast cancer tissue microarrays were included in the same slides.

\section{Cell treatments}

NCI-H295R cells and ACC primary cultures were seeded in 24-well plates and cultured in complete medium. Before treatment, culture medium was switched into charcoal-dextran-treated Nu-Serum (cNS)-medium with increasing concentrations of progesterone $(0.1-160 \mu \mathrm{M})$ and/or mitotane $(25$ $\mathrm{nM}-40 \mu \mathrm{M}$ ) for 4 days. Both progesterone and mitotane were dissolved in DMSO. NCI-H295R cells were also exposed to mifepristone $(0.1 \mathrm{nM}-500 \mathrm{nM})$ in combination with progesterone $(25 \mu \mathrm{M})$ for 4 days. Mifepristone and mitotane were supplied by Selleckchem Chemicals (DBA Italia, Milan, Italy) and progesterone was purchased from Sigma Italia (Milan, Italy). SW13 cells were seeded in 24-well plates and cultured in complete medium. Before treatment, culture medium was switched into charcoal-dextran-treated FBS-medium with increasing concentrations of progesterone $(0.1-100$ $\mu \mathrm{M}$ ) for 3 days. Cell exposure to DMSO alone did not modify cell viability in any of the cell cultures used.

\section{Cell viability assay}

Cell viability was evaluated by 3-(4,5-Dimethyl-2-thiazol)-2,5-diphenyl-2H-tetrazolium bromide (MTT) dye reduction assay according to the manufacturer's protocol (Sigma Italia, Milan, Italy). Absorbance was measured by a spectrophotometer at 540/620 nm (GDV, Rome, Italy).

\section{Drug combination experiments}

Progesterone and mitotane combination experiments were performed to evaluate their interaction on NCI-H295R cell viability, according to the Chou and Talalay method [20]. Cells were treated for 4 days with progesterone $(0.1-160 \mu \mathrm{M})$ and mitotane alone $(25 \mathrm{nM}-40 \mu \mathrm{M})$ or with progesterone in combination with mitotane at a fixed ratio (progesterone : mitotane $=4: 1$ ), as recommended for the most efficient data analysis [21, 22]. Cells were analyzed for cell viability using MTT. Data were then converted to Fraction affected $(\mathrm{Fa}$, range from 0 to 1 where $\mathrm{Fa}=0$ indicating $100 \%$ of cell viability and $\mathrm{Fa}=1$ indicating $0 \%$ of cell viability) and analyzed using the CompuSyn software 
141 (ComboSyn inc. Paramus, NJ, USA) to calculate the Combination Index (CI), being the CI value <

1

142 3

4

153

6

144 8 195 11

0.9 an indication of synergism, a $\mathrm{CI}=0.9-1.1$ an indication of additive effect and $\mathrm{CI}>1.1$ and indication of antagonism.

\section{Quantitative RT-PCR (qRT-PCR)}

Gene expression was evaluated by qRT-PCR (ViiA7 Real-Time PCR System, ThermoFisher Scientific, Milan, Italy), using SYBR Green as fluorochrome, as described elsewhere [23]. The sequences of sense and antisense oligonucleotide primers are listed in Supplemental Table 1. Differences in the threshold cycle $\mathrm{Ct}$ values between the beta-actin housekeeping gene and the studied genes $(\Delta \mathrm{Ct})$ were then calculated as an indicator of the amount of mRNA expressed.

\section{Western Blot}

Whole cell lysates were prepared in ice-cold buffer with protease and phosphatase inhibitor cocktails (Roche, Milan, Italy) [24]. Equal amounts of protein were separated by electrophoresis on a 4-12\% NuPAGE Bis-Tris Gel System (Life Technologies, Milan, Italy) and electroblotted to a nitrocellulose membrane. Rabbit monoclonal antibody against human Caspase-3 (Cell Signaling Technology, Milan, Italy) [25] were used, both at final concentration $0.1 \mu \mathrm{g} / \mathrm{mL}$. The Erk protein was detected using anti-total Erk and anti-phospho-Erk antibodies (Santa Cruz Biotechnologies, Heidelberg, Germany) [26] at final concentration $0.7 \mu \mathrm{g} / \mathrm{mL}$. Primary antibodies anti-mPR $(0.5 \mu \mathrm{g} / \mathrm{mL}$ final concentration) and anti-PRGMC1 $(1 \mu \mathrm{g} / \mathrm{mL}$ final concentration) were purchased from Abcam (Cambridge, UK) [27] and Santa Cruz Biotechnologies (Heidelberg, Germany) [28]. A mouse monoclonal antibody directed against the N-terminal region of human $\alpha$-Tubulin (Sigma Italia, Milan, Italy) was used to normalize the values. Secondary HRP-labelled anti-rabbit and anti-mouse antibodies (Santa Cruz Biotechnologies, Heidelberg, Germany) were used and the specific signal was visualized by the ECL-LiteAblot Extend Long (Euroclone, Milan, Italy). Densitometric analysis of the immunoblots was performed using the GelPro-Analyzer v 6.0 (MediaCybernetics, Bethesda, MD, USA).

\section{Double staining AO/EtBr}


6

NCI-H295R cells were treated with progesterone $(25 \mu \mathrm{M})$ for 4 days. A double staining with acridine orange $(\mathrm{AO})$ and ethidium bromide $(\mathrm{EtBr})$ was performed to visualize and quantify the number of viable, apoptotic and necrotic cells, as previously described [10]. Cells were examined by a Zeiss LSM 510 META confocal laser-scanning microscope (Carl Zeiss AG, Germany). Several fields, randomly chosen, were digitalized and scored by using the NIH Image J software.

\section{Cell cycle analyses}

Flow cytometric cell cycle analysis was performed as described, with minor modifications [29]. Briefly, untreated and progesterone-treated NCI-H295R cells were fixed, treated with RNase A (12.5 $\mu \mathrm{g} / \mathrm{ml}$ ), stained with propidium iodide (40 $\mu \mathrm{g} / \mathrm{ml}$ ) (Sigma Italia, Milan, Italy) and analyzed by Flow Cytometry using a MACS Quant Analyzer (Miltenyi Biotec GmbH) for cell cycle status. Data were analyzed using FlowJo (TreeStar).

\section{Immunofluorescence}

Cells were grown onto $12 \mathrm{~mm}$ poly-L-lysine coated coverslips and treated with $\mathrm{IC}_{50}$ value of progesterone for 3 days, with or without mifepristone $(100 \mathrm{nM})$. Cells were then fixed in $4 \%$ paraformaldehyde for $20 \mathrm{~min}$ and permeabilized with $0.2 \%$ Triton X-100 in PBS for $1 \mathrm{hr}$. Nonspecific binding was blocked by incubation in PBS containing $0.2 \%$ Triton X-100 and 10\% normal goat serum for $1 \mathrm{hr}$. Cells were then incubated overnight at $4{ }^{\circ} \mathrm{C}$ with anti- $\beta$ catenin primary antibody (14.2 ng/mL, Cell Signaling Technologies, Milan, Italy). After extensive washes, the Alexa Fluor488 anti-rabbit secondary antibody (Life Technologies, Milan, Italy) was applied for $1 \mathrm{hr}$ at room temperature, followed by counterstaining with Hoechst (Sigma Aldrich, Milan, Italy) for 5 min. After rinsing in PBS, coverslips were mounted using FluorPreserve ${ }^{\mathrm{TM}}$ Reagent and cell staining was detected using a Zeiss LSM 510 META confocal laser-scanning microscope (Carl Zeiss AG, Oberkochen, Germany). NIH-ImageJ software was used for image analysis and processing.

\section{Statistical Analysis}


Statistical analysis was carried out using GraphPad Prism software (version 5.02, GraphPad Software, La Jolla, CA, USA). One-way ANOVA with Bonferroni's correction was used for multiple comparisons. Unless otherwise specified, data are expressed as mean \pm S.E.M. of at least three experiments run in triplicate. $P$ values $<0.05$ were considered statistically significant.

\section{Results}

\section{Progesterone effects on NCI-H295R cell viability}

The predominant expression of the intracellular full length $\mathrm{PgR} B$ isoforms was previously described in NCI-H295R cells [10]. The exposure of NCI-H295R cells to increasing concentrations of progesterone $(0.1-160 \mu \mathrm{M})$ for 4 days led to a reduction in NCI-H295R cell viability in a concentration-dependent manner (Fig.1a). Sigmoidal concentration-response function was applied to calculate the $\mathrm{IC}_{50}$ value of progesterone in NCI-H295R cells, which was $25.5 \mu \mathrm{M}$ (95\% confidence interval [CI], 19.9 to 32.9). Time course experiments in NCI-H295R cells treated with progesterone at the $\mathrm{IC}_{50}$ value demonstrated that the reduction of cell viability reached its maximum at 4 days, with no significant change up to 6 days ( $\mathrm{IC}_{50}$ value of $29.6 \mu \mathrm{M}$; $95 \%$ CI 23.6 to 37.0) (data not shown). Pretreatment of NCI-H295R cells with increasing concentration of the PgR antagonist mifepristone (0.1 -500 nM) antagonized the cytotoxic effect elicited by progesterone at its $\mathrm{IC}_{50}$ for 4 days (Fig. $\left.1 \mathrm{~b}\right)$. This provides evidence that the antineoplastic activity of progesterone requires the stimulation of the PgRs. Mifepristone alone (0.1 - 500 nM; 4 days) did not affect NCI-H295R cells viability (data not shown).

Progesterone induces NCI-H295R cells apoptosis, without inducing changes in the cell cycle distribution

To provide explanation on the mechanism underlying the progesterone-induced NCI-H295R cell toxicity, cells were treated with progesterone $(25 \mu \mathrm{M} ; 4$ days $)$ and stained with $\mathrm{AO} / \mathrm{EtBr}$. Progesterone deeply increased the number of apoptotic cells $39 \pm 2 \%$; while necrotic and living cells were $2 \pm 2 \%$ and $59 \pm 3 \%$ respectively (apoptotic cells: untreated vs treated cells: $P<0.001$ Fig. 2 a). 
Time-course experiments were conducted and our results demonstrated that after 2 days of treatment, 1 the effect is as follow: $93 \pm 1 \%$ living cells, $7 \pm 1 \%$ apoptotic cells and no necrotic cells (apoptotic

cells: untreated vs treated cells: $P<0.05$; Supplemental Fig.1a). Progesterone-induced apoptotic cytotoxicity reached its maximum after 4 days of treatment, as above indicated, and it was not modified if cells were exposed to progesterone up to 6 days: $47 \pm 1 \%$ living cells, $43 \pm 3 \%$ apoptotic cells, $10 \pm 1 \%$ necrotic cells (apoptotic cells: untreated vs treated cells: $P<0.001$; Supplemental Fig.1b). We next examined the expression of total Caspase- 3 and the cleaved-Caspase-3, that play a central role in the execution phase of cell apoptosis [30], in progesterone-treated NCI-H295R cells in comparison to untreated cells (Fig.2b). Progesterone exposure for $48 \mathrm{hrs}$ significantly increased the expression of cleaved-Caspase-3 (\% of increase: $23.9 \pm 1.6$ ) while total Caspase-3 levels were not affected. The analyses of the cell cycle progression by flow cytometry in untreated and progesteronetreated NCI-H295R cells did not show significant differences in cell distribution up to 4 days of treatment (Fig.2c). However, we observed that treatment with progesterone for 4 days increased the proportion of cells in the sub-G0 phase: $29.7 \pm 4.6 \%$ untreated cells, $50.3 \pm 5.1 \%$ progesterone-treated cells $(P<0.05)$, suggestive of DNA fragmentation. Taken together these observations suggest that apoptosis is the main mechanism mediating the progesterone cytotoxicity.

\section{Effect of progesterone on $\beta$-catenin nuclear translocation in NCI-H295R cells}

NCI-H295R cells were treated with progesterone and analyzed for $\beta$-catenin localization using immunofluorescence analyses. At baseline, $\beta$-catenin was highly expressed in the nucleus (Fig.3a), whereas the cell exposure to progesterone at its $\mathrm{IC}_{50}$ reduced $\beta$-catenin nuclear localization and increased its retention into cytoplasm (Fig.3b). The effect of progesterone in sequestering $\beta$-catenin in cytoplasm was counteracted by $100 \mathrm{nM}$ mifepristone (Fig.3c). Immunofluorescence quantification using ImageJ software, reported in Table 2, demonstrated that progesterone significantly reduced $\beta$ catenin nuclear localization. The progesterone-induced reduction of nuclear $\beta$-catenin induced the decrease of mRNA expression of some of its target genes, namely MYC and survivin, while the 
mRNA expression level of another gene, CCND1, resulted unchanged by progesterone treatment (Supplemental Fig.2).

\section{mPR and PGRMC1}

As underlined in the Introduction, accumulating evidence suggests that rapid progesterone responses are mediated by activation of mPRs [31]. In order to evaluate whether or these receptors could contribute to the observed progesterone cytotoxic effect on NCI-H295R, we firstly evaluated their expression. As shown in Supplemental Fig.3a, NCI-H295R expressed mPRs. These receptors were functionally active, as, when cells were treated with the $\mathrm{IC}_{50}$ value of progesterone, we observed a reduction of phospho-Erk protein level (\% of decrease: $30.39 \pm 1.14$ ) at very early time, namely 15 , after progesterone exposure (Supplemental Fig.3b). Finally, we demonstrated that NCI-H295R expressed as well the PGRMC1 (Supplemental Fig.3a).

\section{Progesterone enhanced NCI-H295R cytotoxicity induced by mitotane in drug-combination} treatments

To evaluate whether progesterone treatment of NCI-H295R cells could enhance the cytotoxicity of mitotane, the combination index (CI) was calculated according to the Chou-Talalay method [21]. NCI-H295R cells were firstly exposed to increasing concentrations of mitotane ( $25 \mathrm{nM}-40 \mu \mathrm{M})$ for 4 days and analyzed for cell viability by MTT assay. Sigmoidal concentration-response function was used to calculate the $\mathrm{IC}_{50}$ value, which was $3 \mu \mathrm{M}$ (95\% CI, 2.08 to 4.34) (Fig.4a). The cytotoxic effect of progesterone in combination with mitotane was evaluated at the 1:4 fixed molar ratio for 4 days (Fig.4b). We found that in NCI-H295R cells, the combination had a synergistic cytotoxic effect as compared to each single compound at a $\mathrm{Fa}=0.09-0.86$ with range of CI: 0.08 to 0.88 (Fig.4c).

\section{Progesterone exerted cytotoxic effect in primary human ACC cells}

Primary cultures derived from ACC patients were treated with increasing concentrations of progesterone for 4 days and analyzed for cell viability by MTT assay. In cortisol-secreting ACC cells (ACC01, ACC02 and ACC16), progesterone exerted a concentration-dependent inhibition of cell viability with $\mathrm{IC}_{50}$ values of $18 \mu \mathrm{M}$ (95\% CI 11.4 to 31.7$), 32.9 \mu \mathrm{M}(95 \%$ CI 26.5 to 40.9$)$ and 39.2 
$\mu \mathrm{M}(95 \% \mathrm{CI} 31.8$ to 48.4$)$ respectively. Immunohistochemical analyses of PgR expression in ACC01, ACC02 and ACC16 tumors showed that at least $40 \%$ of neoplastic cells were positive for PgR (Table 1). By contrast, a lesser cytotoxic effect of progesterone was observed in the non-secreting human ACC cells, ACC03 and ACC08, with $\mathrm{IC}_{50}$ values of $73.4 \mu \mathrm{M}(95 \%$ CI 46.1 to 116.8$)$ and $80.8 \mu \mathrm{M}$ (95\% CI 50.5 to 129.5 ) respectively (Fig.5). PgR expression in these cells was detected in less than $5 \%$ of ACC cells (Table 1).

\section{Progesterone effect on SW13 cell line.}

Finally, as an internal control, we tested the effect of progesterone in the non steroidogenic SW13 cell line, that belongs from a small cell carcinoma of adrenal and which exact histopathological features are still under investigation [32]. We firstly analyzed the mRNA expression of PgRs and results indicated that SW13 cells were devoid of PgR: indeed, q-RT-PCR analysis revealed a not detectable PgR mRNA expression in this cell line compared to the $\Delta \mathrm{Ct}$ of $9.01 \pm 0.25$ in NCI-H295R cells, used as positive control. The western blot analysis of mPR and PGRMC1 expression in SW13 cell line indicated that these receptor proteins were expressed in this cell line (Supplemental Figure 4a). When exposed to increasing concentrations of progesterone within the same range of concentrations used for NCI-H295R cells, a cytotoxic effect could be observed, although it was non concentration-dependent (Supplemental Fig.4b).

\section{Discussion}

In the present study, we demonstrated that progesterone, through its receptors, exerted a concentration-dependent and time-dependent inhibition of ACC cell viability, and this effect was, at least in part, counteracted by the PgR antagonist mifepristone. The role of PgR is further supported by data published by our group, where the PgR silencing induces the almost complete disappearance of the effect of abiraterone on cell viability [10]. The cytotoxic effect of progesterone was observed in the NCI-H295R cells, an ACC cell line that mainly express the full length PgR B isoform [10, 33] and confirmed in primary cell cultures derived from cortisol-secreting ACC that are characterized by 
a marked expression of the PgR. Indeed, the cytotoxic effect of progesterone was less evident in nonsecreting ACC tumors in which PgR expression was low. Intriguingly, we demonstrated that NCI-

effects that we observed in ACC cells, both in cell line and primary cultures, could be a result of a multifactorial process involving both genomic and non-genomic actions, dependent on both membrane and intracellular progesterone receptor arrangement expressed by each ACC tumor. The scenario is even more complex than expected, in light of the evidence showing that the different effect of progesterone depends on many variables, such as the type of cells, the genomic and/or non genomic effects linked to the progesterone receptor expression and the concentration of hormone present [34]. As a matter of fact, we observed that the non steroidogenic SW13 cell line, established from a small cell carcinoma of the adrenal [35], was responsive to the cytotoxic effect of progesterone (although without displaying a concentration-dependent curve ) despite they expressed only mPR and PGRMC1. On the basis of these preliminary results the characterization of expression and function of all receptor components of progesterone pathway in our experimental models is now undergoing in our lab.

The present results confirm and extend our previous study [10] showing that the in vitro antineoplastic activity of abiraterone is mediated by the drug-induced increase in progesterone levels. PgRs, therefore, could represent a novel promising target in the management of ACC.

In PgR-positive breast cancer cell lines, progestins can induce a growth arrest due to decreased expression and activity of cyclin-dependent kinase (cdk) complexes [36]. In the present study, we showed that the progesterone-induced cytotoxicity of NCI-H295R ACC cells was not cell cycle mediated, but apoptosis represented the main molecular events, with a significant increase of the proapoptotic cleaved-Caspase-3 levels in the initial phase of the treatment. The ability of progesterone in modulating apoptotic events, both in vitro and in vivo, was previously demonstrated in several tumor cells [37-41]. On the light of these results, we therefore explored the possible molecular mechanism regulating the progesterone-induced apoptosis in ACC. 
The Wnt/ $\beta$-catenin pathway is frequently altered in ACC, which is characterized by CTNNB1 mutations leading to $\beta$-catenin accumulation in the nucleus, where it binds with the $\mathrm{T}$ cell factor (Tcf) and enhances its transcriptional activity. In the NCI-H295R cell line, harboring the activating CTNNB1 p.S45P mutation, we found that progesterone treatment partially inhibited the $\beta$-catenin translocation into the nucleus, thus suggesting the involvement of this pathway in the progesterone antineoplastic activity. These data are in line with our previous in vitro experiments showing that the increased levels of progesterone in NCI-H295R cell culture microenvironment, induced by the block of the CYP17A1 by abiraterone, significantly inhibited the $\beta$-catenin migration into the nucleus. Further evidence comes from studies showing that progesterone is able to inhibit the $\mathrm{Wnt} / \beta$-catenin pathway in endometrial carcinoma [42]. The functional effect of the $\beta$-catenin modification of traslocation is the down-regulation of the expression of some $\beta$-catenin target genes, namely MYC and survivin, while CCND1 was not modified.

Taken together these data are suggestive for an involvement of $\beta$-catenin inhibition in the progesterone induced apoptosis of ACC cells. These data, however, are not exhaustive and the full evidence of the inhibitory effect would require the demonstration of a modulation of the expression of other specific $\beta$-catenin target genes in NCI-H295R cells by progesterone treatment. These further experiments are outside the scope of the present paper and will be a matter of a future study.

Finally, the in vitro demonstration of the synergistic cytotoxic effect of the combination mitotane + progesterone could be of considerable interest for its possible clinical application, as progesterone and its derivatives are already part of the supportive approach in cancer patients . These preclinical data provides the rationale for a new trial testing the efficacy of progesterone $\mathrm{n}$ association with current systemic therapies in the management of ACC patients.

In conclusion, the present study shows that progesterone exerts a cytotoxic activity in ACC cells, by inducing apoptosis via activation of the progesterone receptors. Both the genomic and non-genomic effects of progesterone seemed to mediate the cytotoxicity, although this point is still under 
investigation. The synergistic cytotoxic activity of progesterone with mitotane provides the rationale for testing this combination in a prospective clinical study.

\section{References}

1. C.L. Ronchi, M. Kroiss, S. Sbiera, T. Deutschbein, M. Fassnacht:. EJE prize 2014: current and evolving treatment options in adrenocortical carcinoma: where do we stand and where do we want to go? Eur. J. Endocrinol. 171, R1-R11 (2014)

2. M. Terzolo, F. Daffara, A. Ardito, B. Zaggia, V. Basile, L. Ferrari, A. Berruti: Management of adrenal cancer: a 2013 update. J. Endocrinol. Invest. 37, 207-17 (2014)

3. A. Berruti, E. Baudin, H. Gelderblom, H.R. Haak, F. Porpiglia, M. Fassnacht, G. Pentheroudakis: ESMO Guidelines Working Group. Adrenal cancer: ESMO Clinical Practice Guidelines for diagnosis, treatment and follow-up. Ann. Oncol. 23 Suppl 7, 131-138 (2012)

4. M. Fassnacht, M. Terzolo, B. Allolio, E. Baudin, H. Haak, A. Berruti, S. Welin, C. SchadeBrittinger, A. Lacroix, B. Jarzab, H. Sorbye, D.J Torpy, V. Stepan et al: Combination chemotherapy in advanced adrenocortical carcinoma. N. Engl. J Med. 366, 2189-2197 (2012)

5. A. Berruti, M. Terzolo, P. Sperone, A. Pia, S. Della Casa, D.J. Gross, C. Carnaghi, P. Casali, F. Porpiglia, F. Mantero, G. Reimondo, A. Angeli, L. Dogliotti: Etoposide, doxorubicin and cisplatin plus mitotane in the treatment of advanced adrenocortical carcinoma: a large prospective phase II trial. Endocr. Relat. Cancer. 12, 657-666 (2005)

6. A. Berruti, M. Fassnacht, H. Haak, T. Else, E. Baudin, P. Sperone, M. Kroiss T. Kerkhofs, A.R. Williams, A. Ardito, S. Leboulleux, M. Volante, T. Deutschbein, R. Feelders, C. Ronchi, S. Grisanti, H. Gelderblom, F. Porpiglia, M. Papotti, G.D. Hammer, B. Allolio, M. Terzolo: Prognostic role of overt hypercortisolism in completely operated patients with adrenocortical cancer. Eur. Urol. 65 , $832-838(2014)$

7. R. Libé, I. Borget, C.L. Ronchi, B. Zaggia, M. Kroiss, T. Kerkhofs, J. Bertherat, M. Volante, M. Quinkler, O. Chabre, M. Bala , A. Tabarin, F. Beuschlein et al.: Prognostic factors in stage III-IV 
6

adrenocortical carcinomas (ACC): an European Network for the Study of Adrenal Tumor (ENSAT) study. Ann. Oncol. 26, 2119-2125 (2015)

8. M. Volante, C. Buttigliero, E. Greco, A. Berruti, M. Papotti: Pathological and molecular features of adrenocortical carcinoma: an update. J Clin Pathol. 61, 787-793 (2008)

9. Puglisi S, Perotti P, Cosentini D, Roca E, Basile V, Berruti A, Terzolo M. Decision-making for adrenocortical carcinoma: surgical, systemic, and endocrine management options. Expert Rev Anticancer Ther. 2018 Aug 21:1-9.

10. C. Fiorentini, M. Fragni, P. Perego, S. Vezzoli, S.A. Bonini, M. Tortoreto, D. Galli, M. Claps, G.A. Tiberio, M. Terzolo, C. Missale, M. Memo, G. Procopio, N, Zaffaroni, A. Berruti, S. Sigala: Antisecretive and Antitumor Activity of Abiraterone Acetate in Human Adrenocortical Cancer: A Preclinical Study. J. Clin. Endocrinol. Metab. 101, 4594-4602 (2016)

11. G. Attard, A.H. Reid, R.J Auchus, B.A. Hughes, A.M. Cassidy E. Thompson, N.B. Oommen, E. Folkerd, M. Dowsett W. Arlt, J.S. de Bono: Clinical and biochemical consequences of CYP17A1 inhibition with abiraterone given with and without exogenous glucocorticoids in castrate men with advanced prostate cancer. J. Clin. Endocrinol. Metab. 97, 507-516 (2012)

12. A. Pia, F. Vignani, G. Attard, M. Tucci, P. Bironzo, G. Scagliotti, W. Arlt, M. Terzolo, A. Berruti:Strategies for managing ACTH dependent mineralocorticoid excess induced by abiraterone. Cancer. Treat. Rev. 39, 966-973 (2013)

13. M. Claps, B. Lazzari, S. Grisanti, V. Ferrari M. Terzolo, S. Sigala, S. Vezzoli, M. Memo, M. Castellano, A. Berruti: Management of severe Cushing's syndrome induced by adrenocortical carcinoma with abiraterone acetate: a case report. AACE Clinical Reports. 2, 337-341 (2016) 14. A. Salomon, M. Keramidas, C. Maisin, M. Thomas: Loss of $\beta$-catenin in adrenocortical cancer cells causes growth inhibition and reversal of epithelial-to-mesenchymal transition. Oncotarget 6, $11421-11433(2015)$

15. D. Garg, S.S.M Ng K.M. Baig, P. Driggers, J. Segars: Progesterone-Mediated Non-Classical Signaling. Trends Endocrinol. Metab. 28, 656-668 (2017) 
16. R.L. Ashley, C.M. Clay, T.A. Farmerie, G.D. Niswender, T.M. Nett: Cloning and characterization of an ovine intracellular seven transmembrane receptor for progesterone that mediates calcium mobilization. Endocrinology. 147, 4151-4159 (2006)

17. V. Boonyaratanakornkit, N. Hamilton, D.C. Márquez-Garbán, P. Pateetin, E.M. McGowan, R.J. Pietras: Extranuclear signaling by sex steroid receptors and clinical implications in breast cancer. Mol. Cell. Endocrinol. 466, 51-72 (2018)

18. W.E. Rainey, K. Saner, B.P. Schimmer: Adrenocortical cell lines. Mol. Cell. Endocrinol. 228, 23$38(2004)$

19. E.N. Kornaga A.C. Klimowicz, N. Guggisberg, T. Ogilvie, D.G. Morris, M. Webster, A.M. Magliocco: A systematic comparison of three commercial estrogen receptor assays in a single clinical outcome breast cancer cohort. Mod. Pathol. 29, 799-809 (2016)

20. T.C. Chou, P. Talalay: Quantitative analysis of dose-effect relationships: the combined effects of multiple drugs or enzyme inhibitors. Adv. Enzyme. Regul. 22, 27-55 (1984)

21. T.C. Chou: Theoretical basis, experimental design, and computerized simulation of synergism and antagonism in drug combination studies. Pharmacol. Rev. 58, 621-681 (2006)

22. J. Hofman, D. Ahmadimoghaddam, L. Hahnova, P. Pavek, M. Ceckova, F. Staud: Olomoucine II and purvalanol A inhibit ABCG2 transporter in vitro and in situ and synergistically potentiate cytostatic effect of mitoxantrone. Pharmacol. Res. 65, 312-319 (2012)

23. S. Sigala, S. Bodei, C. Missale, D. Zani, C. Simeone, S.C. Cunico, P.F. Spano: Gene expression profile of prostate cancer cell lines: effect of nerve growth factor treatment. Mol. Cell. Endocrinol. 284, 11-20 (2008)

24. C. Fiorentini, S. Bodei, F. Bedussi, M. Fragni, S.A. Bonini, C. Simeone, D. Zani, A. Berruti, C. Missale, M. Memo, P.F. Spano, S. Sigala: GPNMB/OA protein increases the invasiveness of human metastatic prostate cancer cell lines DU145 and PC3 through MMP-2 and MMP-9 activity. Exp. Cell. Res. 323, 100-111 (2014) 
25. V. Porrini I. Sarnico, M. Benarese, C. Branca, M. Mota, A. Lanzillotta, A. Bellucci, E. Parrella, L. Faggi, P.F. Spano, B.P. Imbimbo, M. Pizzi: Neuroprotective and Anti-Apoptotic Effects of CSP1103 in Primary Cortical Neurons Exposed to Oxygen and Glucose Deprivation. Int. J. Mol. Sci. 18 (2017)

26. M. Babagana, S. Johnson, H. Slabodkin, W. Bshara, C. Morrison, E.S. Kandel: P21-activated kinase 1 regulates resistance to BRAF inhibition in human cancer cells. Mol. Carcinog. 56, 1515$1525(2017)$

27. N.M. Bashour S. Wray:Progesterone Directly and Rapidly Inhibits GnRH Neuronal Activity via Progesterone Receptor Membrane Component 1 Endocrinology. Endocrinology. 153, 4457-4469 (2012)

28. V. Lodde, J.J. Peluso: A novel role for progesterone and progesterone receptor membrane component 1 in regulating spindle microtubule stability during rat and human ovarian cell mitosis. Biol. Reprod. 84, 715-722 (2011)

29. A. Chimento A, Sirianni R, Casaburi I, Zolea F, Rizza P, Avena P, Malivindi R, De Luca A, Campana C, Martire E, Domanico F, Fallo F, Carpinelli G, Cerquetti L, Amendola D, Stigliano A, Pezzi V. GPER agonist G-1 decreases adrenocortical carcinoma (ACC) cell growth in vitro and in vivo. Oncotarget. 6, 19190-19203 (2015)

30. R.S.Y. Wong: Apoptosis in cancer: from pathogenesis to treatment. J. Exp. Clin. Cancer. Res. 30$87(2011)$

31. A.O. Mueck, X. Ruan, H. Seeger, T. Fehm, H. Neubauer: Genomic and non-genomic actions of progestogens in the breast. J. Steroid. Biochem. Mol. Biol. 142, 62-67 (2014)

32. T. Wang, W.E. Rainey: Human adrenocortical carcinoma cell lines. Mol Cell Endocrinol. 351, $58-65(2012)$

33. K.M. Scarpin, J.D. Graham, P.A. Mote, C.L. Clarke: Progesterone action in human tissues: regulation by progesterone receptor (PR) isoform expression, nuclear positioning and coregulator expression. Nucl. Recept. Signal. 7: e009 (2009) 
34. J.H. Check: The role of progesterone and the progesterone receptor in cancer. Expert Rev Endocrinol Metab. 12, 187-197 (2017)

35. A. Leibovitz, W.M. 3rd McCombs, D. Johnston, C.E. McCoy, J.C. Stinson: New human cancer cell culture lines. I. SW-13, small-cell carcinoma of the adrenal cortex. J. Natl. Cancer Inst. 51, 691$697(1973)$

36. V. Boonyaratanakornkit, E. McGowan L. Sherman, M.A. Mancini, B.J. Cheskis, D.P. Edwards: The role of extranuclear signaling actions of progesterone receptor in mediating progesterone regulation of gene expression and the cell cycle. Mol. Endocrinol. 21, 359$375(2007)$

37. S.Z. Bu, D.L. Yin, X.H. Ren, L.Z. Jiang, Z.J. Wu, Q.R. Gao, G. Pei: Progesterone induces apoptosis and up-regulation of p53 expression in human ovarian carcinoma cell lines. Cancer. 79, 1944-1950 (1997)

38. V. Syed, S.M. Ho: Progesterone-induced apoptosis in immortalized normal and malignant human ovarian surface epithelial cells involves enhanced expression of FasL. Oncogene. 22, 6883-6890 (2003)

39. B. Formby, T.S. Wiley: Bcl-2, survivin and variant CD44 v7-v10 are downregulated and p53 is upregulated in breast cancer cells by progesterone: inhibition of cell growth and induction of apoptosis. Mol. Cell. Biochem. 202, 53-61 (1999)

40. K. Horita, N. Inase, S. Miyake, B. Formby, H. Toyoda, Y. Yoshizawa: Progesterone induces apoptosis in malignant mesothelioma cells. Anticancer Res. 21, 3871-3874 (2001)

41. F. Atif, S. Yousuf, D.G. Stein: Anti-tumor effects of progesterone in human glioblastoma multiforme: role of PI3K/Akt/mTOR signaling. J. Steroid. Biochem. Mol. Biol. 146, 62-73 (2015) 42. Y. Wang, P. Hanifi-Moghaddam, E.E. Hanekamp, H.J. Kloosterboer, P. Franken, J. Veldscholte, H.C. van Doorn, P.C. Ewing, J.J. Kim, J.A. Grootegoed, C.W. Burger, R. Fodde, L.J. Blok: Progesterone inhibition of $\mathrm{Wnt} /$ beta-catenin signaling in normal endometrium and endometrial cancer. Clin. Cancer. Res. 15, 5784-5793 (2009) 
43. P. De Cremoux, D. Rosenberg, J. Goussard, C. Brémont-Weil, F. Tissier, C. Tran-Perennou L. Groussin, X. Bertagna, J. Bertherat, M.L. Raffin-Sanson : Expression of progesterone and estradiol receptors in normal adrenal cortex, adrenocortical tumors, and primary pigmented nodular adrenocortical disease. Endocr. Relat. Cancer. 15, 465-674 (2008)

\section{Figure Legends}

Fig. 1: Cytotoxic effect of progesterone in NCI-H295R cells. a. NCI-H295R cells were treated with increasing concentration of progesterone $(0.1-160 \mu \mathrm{M})$ for 4 days. Cell viability was analyzed by MTT assay. Results are expressed as percent of viable cells vs control (ctrl) cells. Data are the mean \pm S.E.M. of three experiments performed in triplicate. ${ }^{* *} P<0.001 \mathrm{vs}$ ctrl. b. Cells were treated with progesterone $(25 \mu \mathrm{M})$ for 4 day in the presence of the PgR antagonist mifepristone $(0.1 \mathrm{nM}-500$ nM). Cell viability was analyzed by MTT assay. Results are expressed as percent of viable cells vs control (ctrl) cells. Data are the mean \pm S.E.M. of three experiments performed in triplicate. $* * P<$ 0.001 vs ctrl.

Fig. 2: Progesterone promotes apoptotic events in NCI-H295R cells, with no influences on cell cycle phases. a. NCI-H295R cells were treated with progesterone $(25 \mu \mathrm{M})$ for 4 days. Untreated (C) and progesterone-treated ( $\mathrm{T}$ ) cells were then stained with $\mathrm{AO} / \mathrm{EtBr}$. Viable (green), apoptotic (yellow) and necrotic (red) cells were scored under a confocal laser-scanning microscope. Magnification, 10x. The images were representative of at least three independents experiments, with superimposable results. b. Cells were treated with progesterone $(25 \mu \mathrm{M})$ for 1-3 days and analysed for Caspase-3 and clevead-Caspase-3 expression using Western Blot (WB). The human $\alpha$-Tubulin was used as internal control. A representative WB is shown. Densitometric analysis of blots $(n=3)$ with specific levels of cleaved-Caspase-3 normalized to the corresponding tubulin levels. Bars represent the mean \pm S.E.M. ${ }^{* *} P<0.01$ vs untreated cells. c. NCI-H295R cells were treated with progesterone $(25 \mu \mathrm{M})$, stained with propidium iodide and analyzed for DNA content by flow cytometry. Histograms representative of one out of three experiments were shown in the figure. 
6

Fig. 3: Progesterone treatment affects the subcellular localization of $\beta$-catenin in NCI-H295R

cells. Cells were treated with progesterone $(25 \mu \mathrm{M})$ alone or in combination with mifepristone (100 $\mathrm{nM}$ ) for 3 days. Untreated (a), progesterone-treated (b) progesterone-mifepristone-treated (c) cells were analyzed for $\beta$-catenin localization following by incubation with Hoechst for nuclear staining. Panels a, d, g: Hoechst; panel b, e, h: $\beta$-catenin; panel c, f, i: merge. The scale bar of $50 \mu \mathrm{m}$ is automatically inserted by the software ZEN Black.

Fig. 4: Effect of the combination of progesterone with mitotane in NCI-H295R cells. a. NCIH295R cells were treated with increasing concentration of mitotane ( $25 \mathrm{nM}-40 \mu \mathrm{M})$ for 4 days. Cell viability was analyzed by MTT assay. Results are expressed as percent of viable cells vs control (ctrl) cells. Data are the mean \pm S.E.M. of three experiments performed in triplicate. $* * P<0.001 \mathrm{vs}$ ctrl. b. NCI-H295R cells exposed to increasing concentrations of progesterone and mitotane alone or in combination at fixed concentration at 1:4 molar ratio (progesterone: mitotane) for 4 days. Data are expressed as percent of viable cells vs control (ctrl) cells. Data are the mean \pm S.E.M. of three experiments performed in triplicate. c. Cell viability from B was converted to Fraction affected (Fa) values and resulting data were analyzed with CompuSyn software to obtain combination index (CI) plot. $\mathrm{Fa}=0,100 \%$ cell viability $\mathrm{Fa}=1,0 \%$ cell viability; $\mathrm{CI}$ value $<0.9$, synergism, $\mathrm{CI}=0.9-1.1$ additive effect and CI > 1.1 antagonism.

Fig. 5: Cytotoxic effect of progesterone in human ACC primary cultures. Cortisol secreting

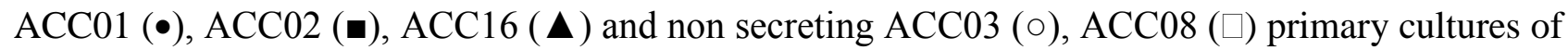
human ACC cells were treated with increasing concentrations of progesterone $(0.1-100 \mu \mathrm{M})$ for 4 days. Cell viability was evaluated by MTT assay. Results are expressed as percent of viable cells vs control (ctrl) cells. Data are the mean \pm S.E.M. of three independent experiments performed in triplicate. ${ }^{*} P<0.01$ vs ctrl; $* * P<0.001$ vs ctrl. 
a
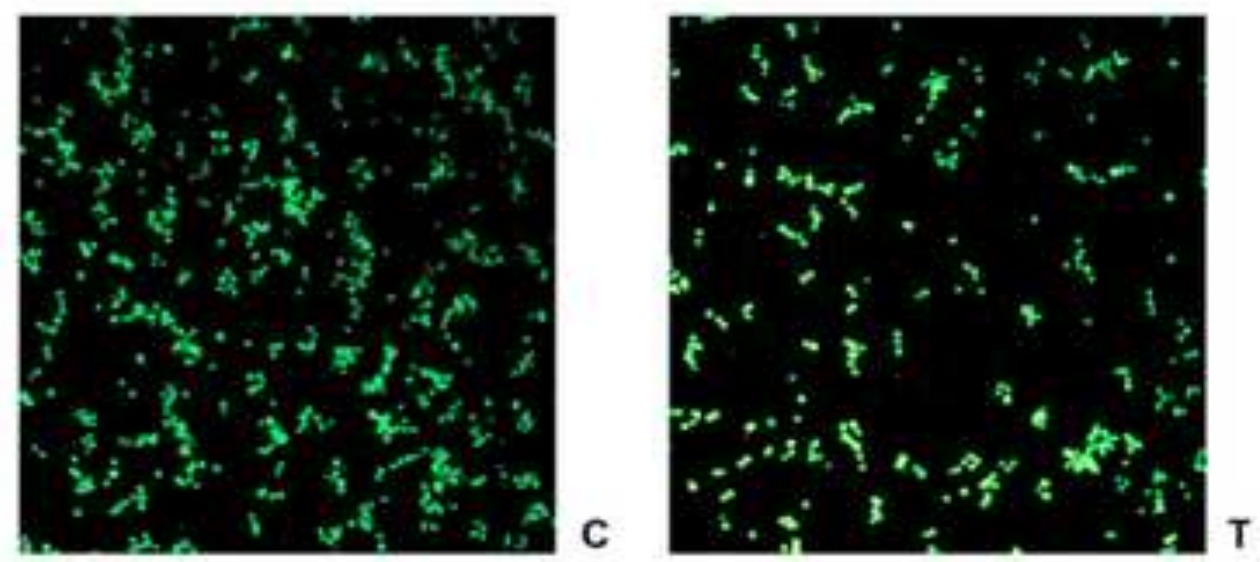

c

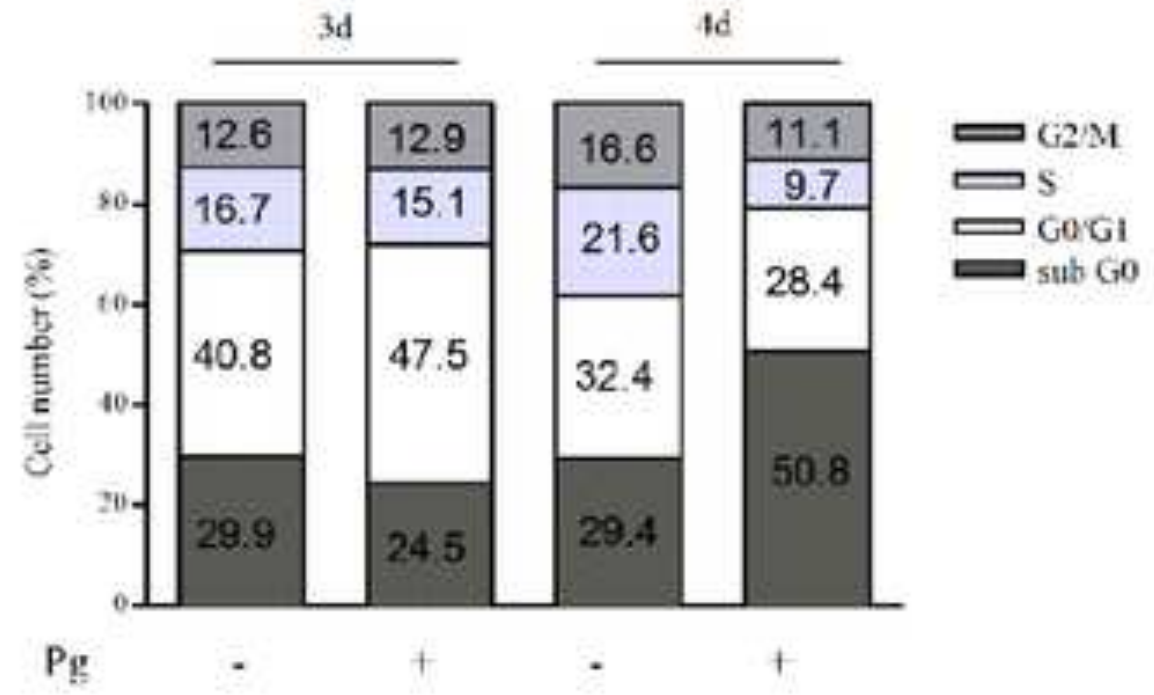

b

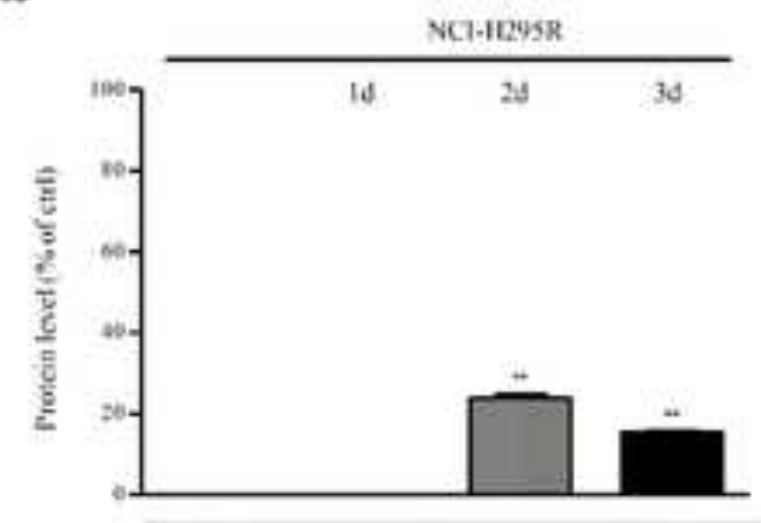

$35 \mathrm{KDa}$

Caspase-3

$17 \mathrm{KDa}$

$50 K D a$

$\mathrm{Pg}-+++$
Tubuln 

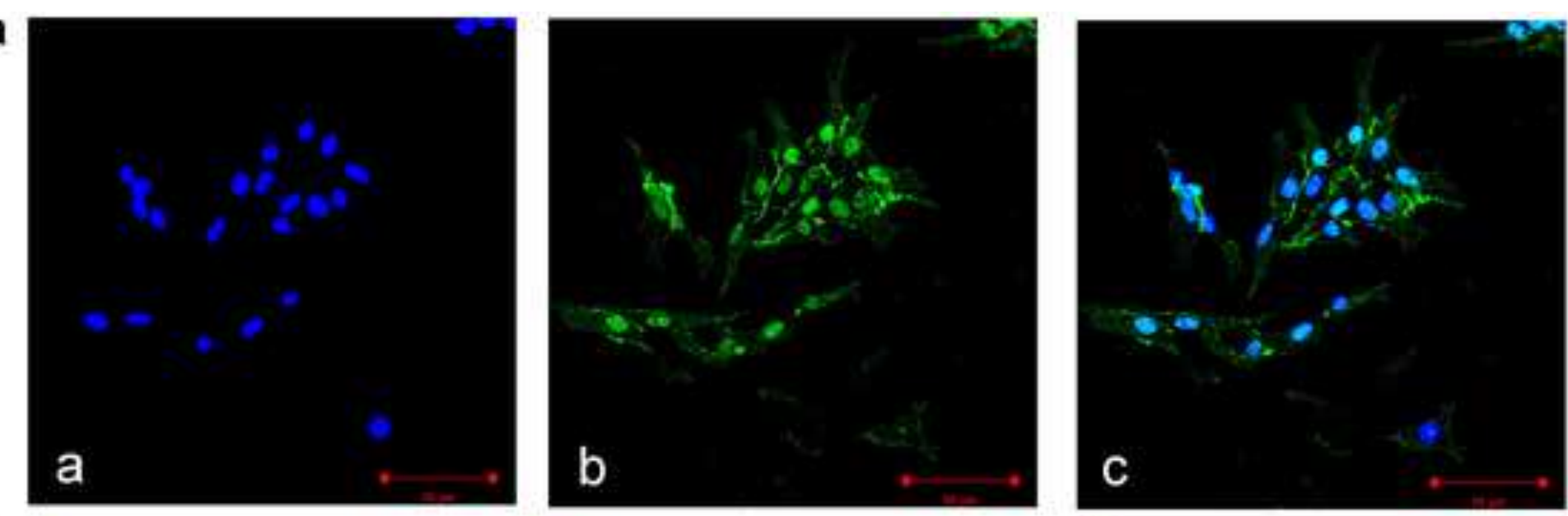

b
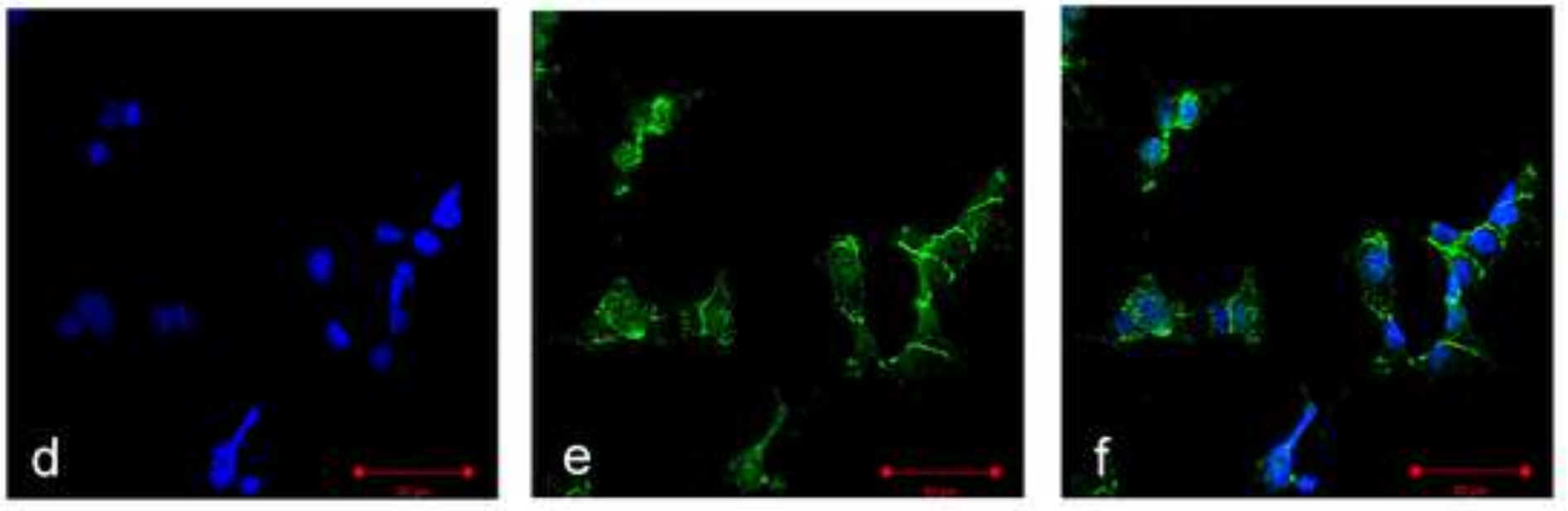

c
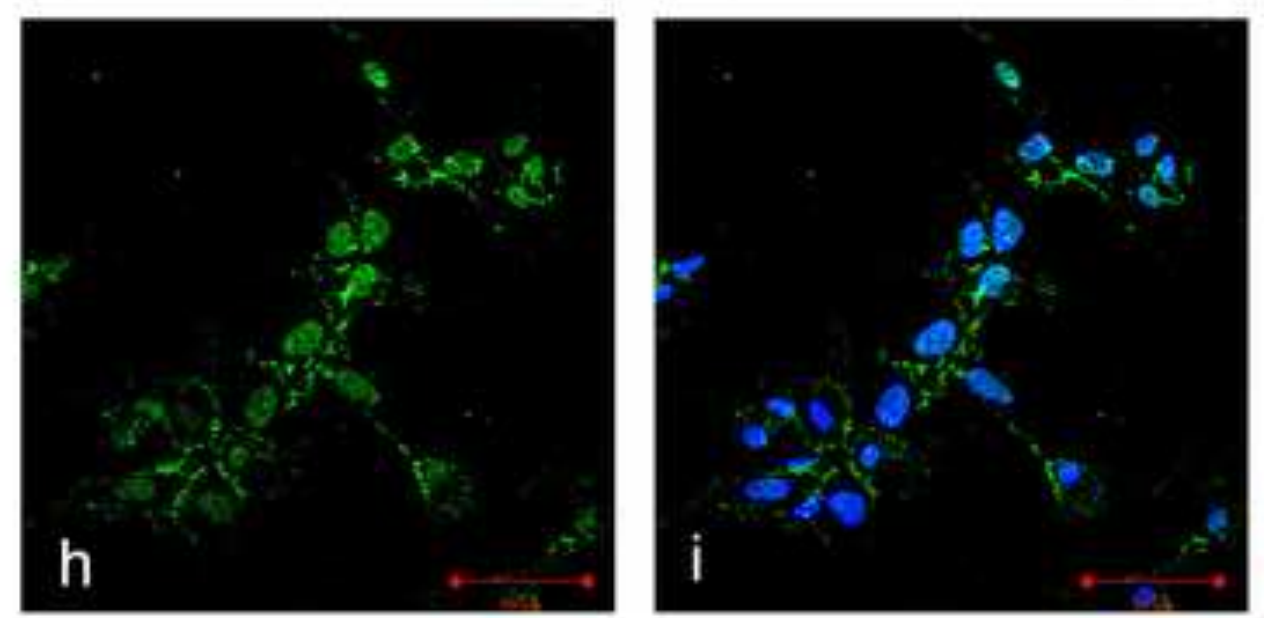
Figure

Click here to access/download;Figure;Fig.4.tif $\underline{\underline{*}}$

a

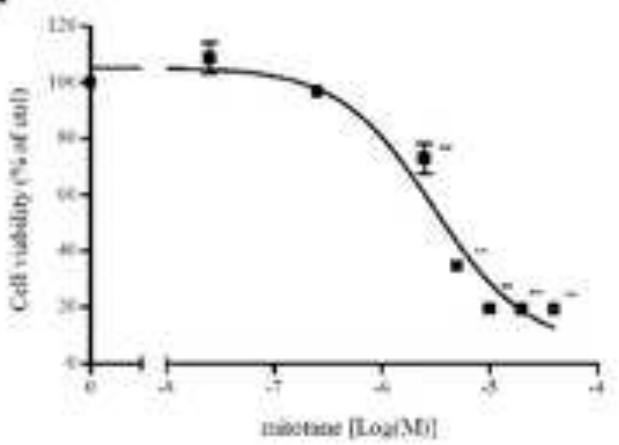

b

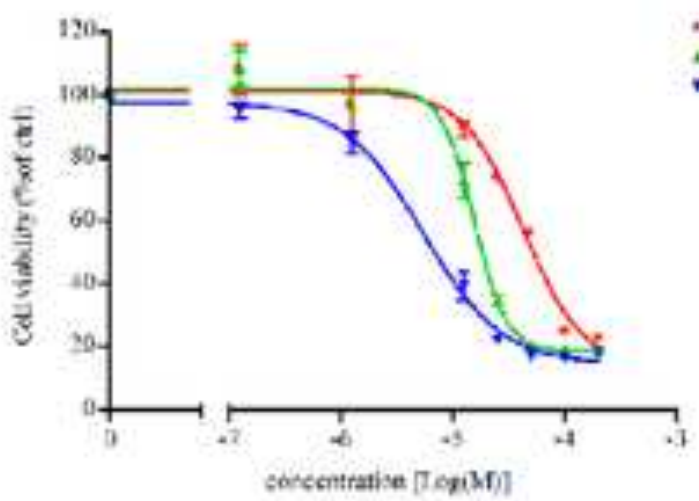

C

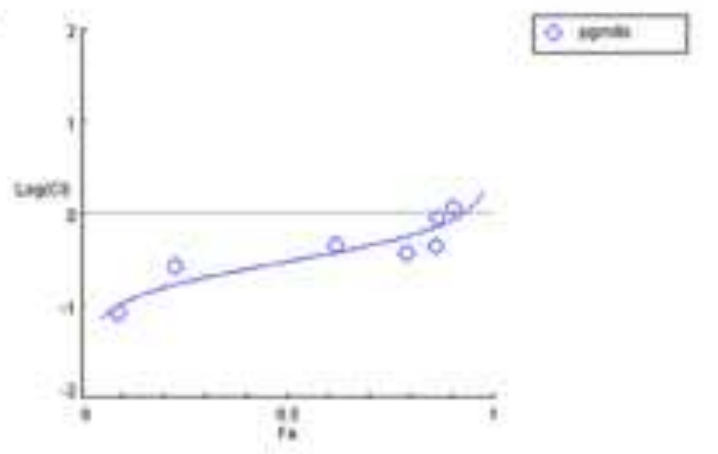




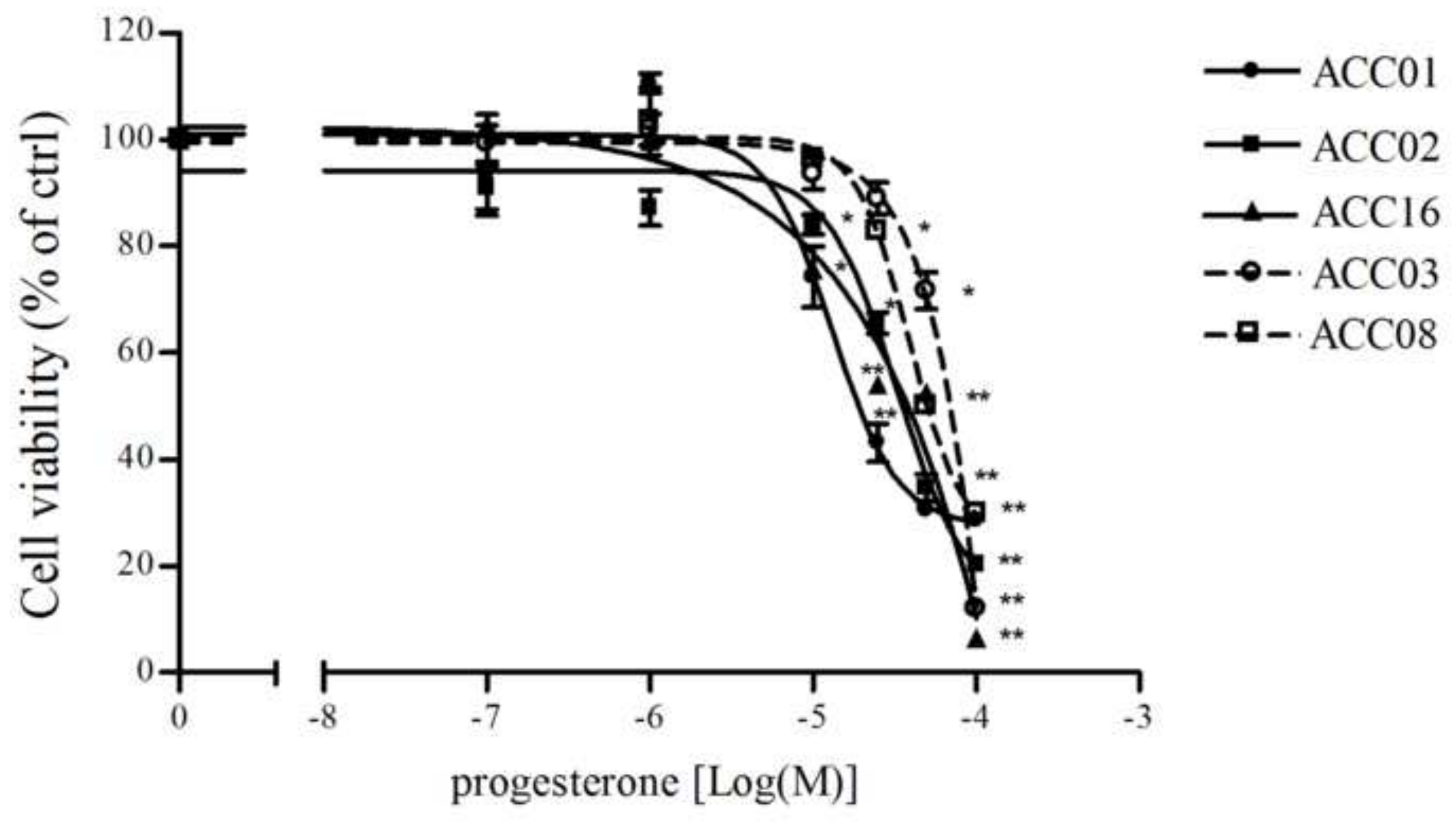


a

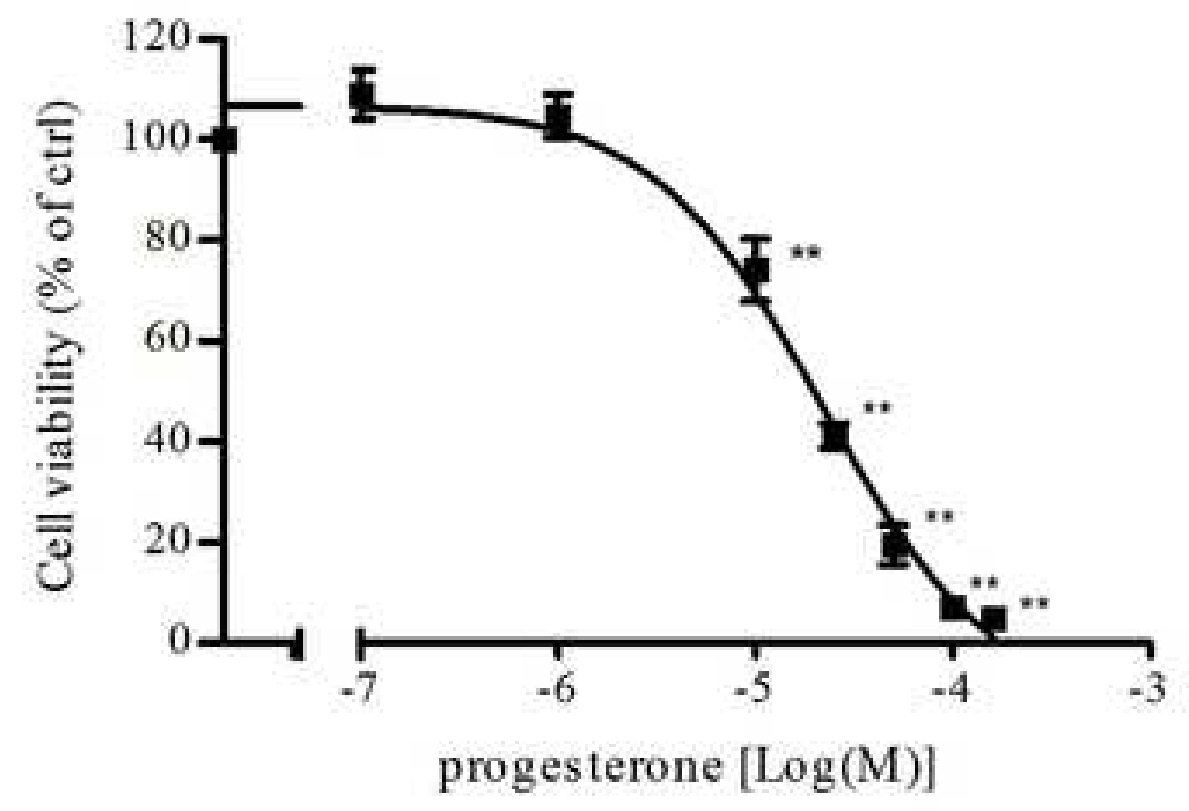

b

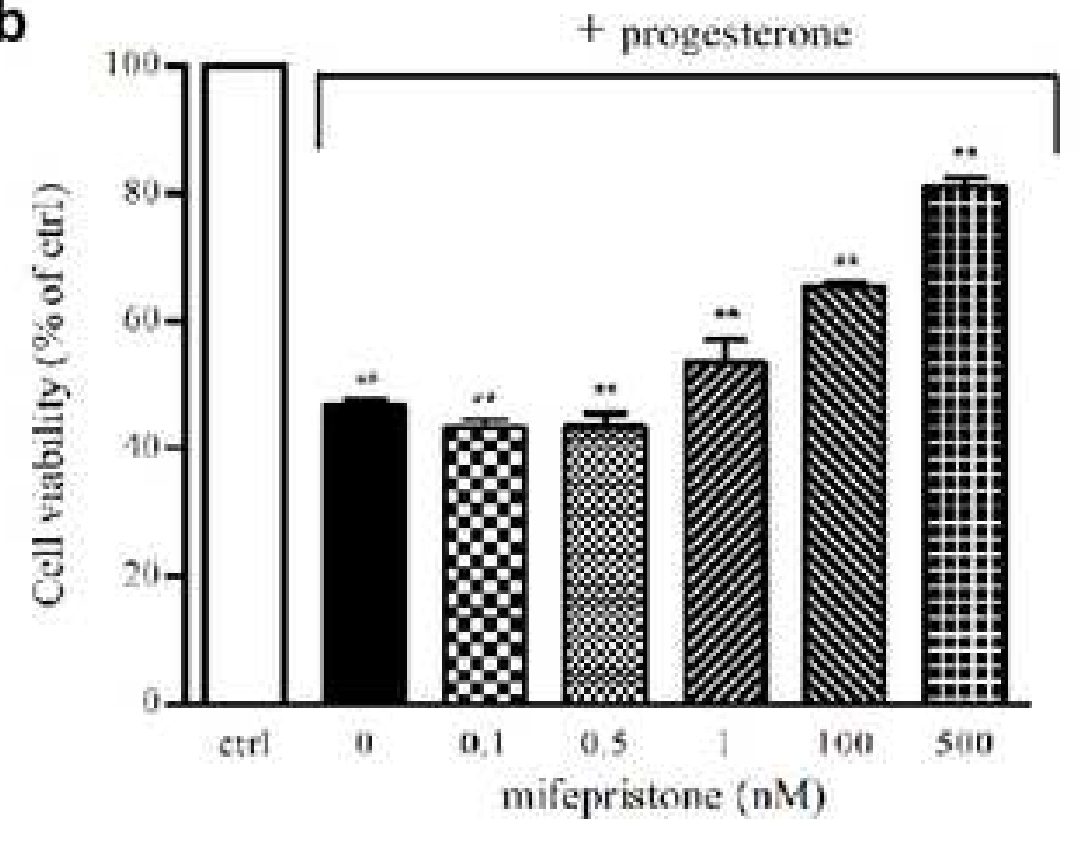


Table 1: Clinical characteristics of ACC patients.

\begin{tabular}{|c|c|c|c|c|c|}
\hline $\begin{array}{l}\text { Primary culture } \\
\text { identification }\end{array}$ & $\begin{array}{l}\text { Tumor } \\
\text { specimen }\end{array}$ & Histology & Disease stage & $\begin{array}{l}\text { Hormone } \\
\text { hypersecretion }\end{array}$ & $\begin{array}{l}\mathrm{PgR} \\
\text { expression }\end{array}$ \\
\hline $\begin{array}{l}\text { ACC01 } \\
\text { Female } \\
66 \text { yr old }\end{array}$ & $\begin{array}{l}\text { Primary } \\
\text { ACC }\end{array}$ & $\begin{array}{l}\text { Weiss score } 8 \\
\text { Mitotic } \\
\text { index: }>50 / 50 \\
\text { HPF Ki67 70\% }\end{array}$ & $\begin{array}{l}\text { Stage IV (hepatic } \\
\text { metastases) }\end{array}$ & $\begin{array}{l}\text { Cortisol (severe } \\
\text { Cushing's syndrome) }\end{array}$ & $40 \%$ \\
\hline $\begin{array}{l}\text { ACC02 } \\
\text { Female } \\
63 \text { yr old }\end{array}$ & $\begin{array}{l}\text { Peritoneal } \\
\text { metastases }\end{array}$ & $\begin{array}{l}\text { Weiss score not } \\
\text { available } \\
\text { Mitotic } \\
\text { index: >50/50 } \\
\text { HPF Ki67 50\% }\end{array}$ & $\begin{array}{l}\text { Stage IV (peritoneal } \\
\text { dissemination) }\end{array}$ & $\begin{array}{l}\text { Cortisol (mild clinical } \\
\text { signs of } \\
\text { hypercortisolism) }\end{array}$ & $70 \%$ \\
\hline $\begin{array}{l}\text { ACC16 } \\
\text { Male } \\
55 \text { yr old }\end{array}$ & $\begin{array}{l}\text { Primary } \\
\mathrm{ACC}\end{array}$ & $\begin{array}{l}\text { Weiss score not } \\
\text { available } \\
\text { Mitotic index: } \\
\text { 10/50 HPF Ki67 } \\
50 \%\end{array}$ & $\begin{array}{l}\text { Stage IV } \\
\text { (bone and multiple } \\
\text { abdominal } \\
\text { lymphonodal } \\
\text { metastases) }\end{array}$ & $\begin{array}{l}\text { Cortisol (severe } \\
\text { Cushing's syndrome) }\end{array}$ & $40 \%$ \\
\hline $\begin{array}{l}\text { ACC03 } \\
\text { Male } \\
59 \text { yr old }\end{array}$ & $\begin{array}{l}\text { Local } \\
\text { relapse of } \\
\text { ACC }\end{array}$ & $\begin{array}{l}\text { Weiss score } 8 \\
\text { Mitotic index: } \\
\text { 25/50 HPF Ki67 } \\
20 \%\end{array}$ & $\begin{array}{l}\text { Stage IV (left } \\
\text { hypochondrium soft } \\
\text { tissue relapse and } \\
\text { peritoneal } \\
\text { dissemination) }\end{array}$ & No secretion & $3-5 \%$ \\
\hline $\begin{array}{l}\text { ACC08 } \\
\text { Female } \\
50 \text { yr old }\end{array}$ & $\begin{array}{l}\text { Lung } \\
\text { metastases }\end{array}$ & $\begin{array}{l}\text { Weiss score } 8 \\
\text { Oncocytic } \\
\text { features } \\
\text { Mitotic index: } \\
\text { 10/50 HPF Ki67 } \\
\text { 20\% }\end{array}$ & $\begin{array}{l}\text { Stage IV (lung and } \\
\text { bone metastases) }\end{array}$ & No secretion & $1-2 \%$ \\
\hline
\end{tabular}


Table 2. Immunofluorescence quantification of $\beta$-catenin expression.

\begin{tabular}{|c|c|c|}
\hline & & $\%$ mean \pm SEM \\
\hline \multirow{2}{*}{ Untreated cells } & nucleus & $51.06 \pm 2.3$ \\
\cline { 2 - 3 } & citoplasm & $48.94 \pm 2.3$ \\
\hline \multirow{2}{*}{ Progesterone-treated cells } & nucleus & $29.01 \pm 3.1$ \\
\cline { 2 - 3 } & citoplasm & $70.99 \pm 3.9 *$ \\
\hline \multirow{2}{*}{$\begin{array}{c}\text { Progesterone }- \text { treated cells in } \\
\text { the presence of mifepristone }\end{array}$} & nucleus & $54.20 \pm 2.3$ \\
\cline { 2 - 3 } & citoplasm & $45.80 \pm 2.6$ \\
\hline
\end{tabular}

Cells were treated with progesterone $(25 \mu \mathrm{M})$ alone or in combination with mifepristone (100 nM) for 3 days.

Quantification was performed using the ImageJ software. Several cells in different fields, randomly chosen, were quantified. ${ }^{*} P<0.001$ vs nuclear localization 


\section{Click here to access/download \\ Supplementary Material
Supplemental Data.docx \\ Supplementary Material
Supplemental Data.docx}

